УДК 633:[620.925:58]:631.559:551.5812

(C) 2017

Кулик М. І., кандидат сільськогосподарських наук,

Рожко I. І., здобувач

(науковий керівник - кандидат сільськогосподарських наук М. І. Кулик)

Полтавська державна аграрна академія

\title{
ВПЛИВ ПОГОДНИХ УМОВ ВЕГЕТАЦИЙНОГО ПЕРІОДУ НА ЕЛЕМЕНТИ ПРОДУКТИВНОСТІ ТА УРОЖАЙНІСТЬ ПРОСА ПРУТОПОДІБНОГО
}

\section{Рецензент - доктор сільськогосподарських наук, професор В. Л. Курило}

3'ясовано вплив погодних умов вететації на мінливість елементів продуктивності (висоти та густоти стеблостою) проса прутоподібного. Визначено вплив середньодобової температури повітря та суми опадів під час вететаиії рослин на урожайність фітомаси культури в розрізі років дослідження. Наведено корелячійні залежності між кількісними показниками рослин (елементами продуктивності) третього-шостого років вететаиії та урожайністю фітомаси проса прутоподібного. Встановлено, щзо урожайність сухої надземної вететативної маси проса прутоподібного в більшій мірі обумовлюється кількістю стебел на одиницю площзі у тісному взаємозв'язку із середньодобовою температурою повітря, в меншій мірі - висотою рослин та сумою опадів за вететаиійний період.

Ключові слова: просо прутоподібне, елементи продуктивності, температура, опади, корелячія, урожайність.

Постановка проблеми. Зменшення енергетичної залежності нашої країни $є$ нагальним питанням сьогодення, адже природні непоновлювані ресурси мають тенденцію до вичерпання, на противагу яким можна використати відновлювані джерела енергії (ВДЕ).

Як відмічає С. О. Кудря [3], Україна має достатній потенціал відновлюваних джерел енергії. Ефективне використання його до 2035 року може забезпечити близько 50 \% загального споживання енергетичних ресурсів 3 відновлюваних джерел енергії. Окрім цього, встановлена потужність електростанцій на основі ВДЕ з 2010 р. зросла в 10 разів і на кінець 2014 р. становила 1462,2 МВт, що відповідає 2,7 \% загальної встановленої потужності електростанцій в Україні.

На даний час наша країна споживає значну кількість енергоресурсів, що в переважній більшості надходять ззовні, а не виробляються в Україні, і тому, проблема енергонезалежності є важливим питанням сьогодення. Саме тому першочерговим завданням $є$ збільшення частки ВДЕ у паливо-енергетичному комплексі на основі створення на маргінальних землях плантацій енерге- тичних культур, як рослинних джерел біопалива. 3 цією метою в якості джерел біомаси передбачається використовувати багаторічні культури, які б були добре адаптованими до умов вирощування, особливо на фоні глобальних змін клімату, що відчуваються уже сьогодні.

Глобальні зміни клімату, за посушливих умов, призводять до зниження рівня концентрації азоту і вуглецю у грунтах, та можуть мати серйозні наслідки для екосистеми в площині виробництва продуктів харчування, отримання енергії, зберігання вуглецю та зниження біорізноманіття.

Як стверджує Девід А. Уардл [12]: «у зв'язку з прогресивними змінами клімату, властивості екосистем у багатьох посушливих районах могли пройти переломний момент, який буде важко або неможливо повернути назад».

Зважаючи на проблематику досліджень, 3 урахуванням глобальних змін клімату та його наслідків, актуальним питанням $\epsilon$ вивчення впливу температури, кількості опадів на ріст і розвиток рослин та рівень урожайності енергетичних культур.

Аналіз основних досліджень і публікацій, у яких започатковано розв'язання проблеми. Як зазначають вітчизняні науковці [7], в Україні існує значний потенціал джерел енергії з біомаси для виробництва біопалива: рослинні рештки сільськогосподарських культур, відходи деревообробної промисловості та енергетичні культури. Останній вид - це переважно багаторічні рослини, які добре акліматизовані до умов навколишнього середовища і здатні формувати високу врожайність фітомаси за їх вирощування на малопродуктивних грунтах. 3-поміж них найбільш перспективні з економічної та екологічної точки зору - міскантус гігантський, просо прутоподібне (світчграс), багаторічна сорго, верба та інші.

За вивчення інтродукції проса прутоподібного в Україні визначено, що ця культура добре адаптована до умов вирощування, має високий стеблостій, формує потужну врожайність фітомаси (сировини для виробництва біопалива) та забез- 
печує стабільну насіннєву продуктивність $[6,9]$.

Просо прутоподібне (Switchgrass) - одна 3 найбільш перспективних рослин для виробництво біоенергії в Сполучених Штатах. Це багаторічна, теплолюбна, зимостійка трав'яниста рослина 3 фотосинтезом C4 шляхом для асиміляції вуглецю. Сорти проса прутоподібного, на основі екологічного походження, поділяють на височинні та низовинні види [18].

Дослідження, проведені зарубіжними науковцями [17], показали, що сорт Кейв-ін-рок має найвищу $\left(7,3^{\circ} \mathrm{C}\right)$ базову температуру проростання насіння, а Дакота - найнижчу $\left(2,8^{\circ} \mathrm{C}\right)$. Coрти, що мають вищу базову температуру, такі як Кейв-ін-рок і Нью-Джерсі-50, показують низькі темпи весняного росту та розвитку рослин, порівняно із сортами, що мають нижчу базову температуру проростання насіння (сорти Дакота i Патфіндер).

Kandel T. Р., досліджуючи вплив температури на ріст і розвиток, інтенсивність фотосинтезу i якість фітомаси проса прутоподібного, визначив екотипні та сортові відмінності між височинними і низинними видами. За вивчення стійкості та толерантності сортів до абіотичних чинників встановив, що 3-поміж низинних сортів Аламо показав ширшу адаптацію в порівнянні з Канлоу, а 3 височинних сортів - Кейв-ін-рок був стійкішим до більш високих температур, ніж сорт Каддо. Усі сорти поставлені на вивчення показали сильну залежність до високотемпературних чинників, оскільки загальний врожай біомаси екотипів проса прутоподібного різко знизився у випадку значного підвищення температури [14].

Подібні експерименти $[11,13]$, що проведені для оцінки впливу температури для енергетичних культур, підтвердили цю думку.

Інші автори [16] за проведення моделювання екосистем зробили висновок, що багаторічне вирощування проса прутоподібного в майбутньому зможе зменшити надходження $\mathrm{CO}_{2} 3$ грунту внаслідок зміни температури та кількості опадів.

Поряд 3 цим, вивчення впливу грунтових та погодних факторів в умовах України на формування урожайності енергетичних культур (за їх вирощування на маргінальних землях), в тому числі проса прутоподібного, за виключенням незначних публікацій $[4,5]$, висвітлено не в повній мірі.

Мета досліджень полягала у встановленні впливу погодних умов вегетаційного періоду на формування кількісних показників рослин та урожайності сухої надземної вегетативної маси проса прутоподібного (Panicum virgatum L.).

Відповідно до мети досліджень передбачалось вирішення наступних завдань:

1. Встановити вплив погодних умов вегетації на мінливість елементів продуктивності (висоти та густоти стеблостою) проса прутоподібного.

2. Визначити вплив гідротермічного коефіцієнта під час вегетації рослин на урожайність фітомаси культури в розрізі років дослідження.

3. Провести кореляційно-регресійний аналіз між кількісними показниками рослин проса прутоподібного та погодними факторами вегетаційного періоду (середньодобової температури повітря та суми опадів).

4. Розрахувати кореляцію між середньодобовою температурою повітря, сумою опадів під час вегетації рослин та урожайністю сухої фітомаси проса прутоподібного.

Методика проведення досліджень. Експериментальна робота виконана на базі Полтавської державної аграрної академії згідно з державною науково-дослідною темою «Агроекологічні засади вирощування енергетичних культур в умовах України» (2014-2017 рр.) та наукового проекту прикладного дослідження МОН України «Розробка оптимальних енергетичних систем з урахуванням наявного потенціалу відновлюваних джерел енергії в умовах Лісостепу України» (2017-2019 pp.).

Дослід реалізовано в умовах центральної частини Лісостепу на маргінальних грунтах, згідно 3 методикою дослідної справи, протягом 20102017 років $з$ сортом проса прутоподібного Кейвін-рок.

За проведення експерименту використовували як загальноприйняті методики [2], так і спеціальні - для закладки, проведення експерименту та обліку кількісних показників рослин $[8,10]$.

Для підвищення достовірності проведення досліджень, кількість стебел та висоту рослин проса прутоподібного визначали як середнє арифметичне значення з 50-ти рослин, відібраних зі снопових зразків з кожного варіанту у чотирьохкратній повторності.

Урожайність надземної вегетативної маси проса прутоподібного визначали шляхом відбору снопових зразків, їхнього зважування, висушування відібраної середньої проби та послідуючим перерахунком на суху масу з урахуванням вологості сировини [15].

Отримані результати досліджень розраховували за допомогою сучасних методів статистики із застосуванням ліцензійних комп'ютерних програм Excel та Statistaca. Коефіцієнти кореляції (r) між кількісними показниками рослин (кількість стебел, висота) і урожайністю сухої фітомаси проса прутоподібного встановлювали за допомогою кореля- 


\section{СІЛЬСЬКЕ ГОСПОДАРСТВО. РОСЛИННИЦТВО}

ційного-регресійного аналізу. Приймалося, якщо $\mathrm{r}<0,3$ - кореляція між ознаками слабка, $\mathrm{r}=0,3-0,7$ - середня та за $\mathrm{r}>0,7$ - сильна [1].

Результати досліджень. Аналіз погодних умов вегетаційного періоду проса прутоподібного за багаторічного циклу вирощування культури свідчить про їх контрастність, що дали можливість оцінити реакцію рослин у розрізі років дослідження (рис. 1-2).

Середньодобова температура повітря протя- гом весняно-літньої вегетації культури у 2012 році змінювалась у межах від 19,4 до $25,6^{\circ} \mathrm{C}$ за середнього значення $21,7^{\circ} \mathrm{C}$, у 2013 році - від 18,6 до $23,3^{\circ} \mathrm{C}$ (середнє $20,9^{\circ} \mathrm{C}$ ), у 2014 році від 13,5 до $25,6^{\circ} \mathrm{C}$ (середнє $20,4^{\circ} \mathrm{C}$ ), у 2015 році - від 13,7 до $23,0^{\circ} \mathrm{C}$ (середнє 19,9 ${ }^{\circ} \mathrm{C}$ ), у 2016 році - від 14,1 до $25,1^{\circ} \mathrm{C}$ (середнє $20,0^{\circ} \mathrm{C}$ ). У зв'язку з чим, ми виокремили 2013, 2014 та 2016 роки, що характеризувалися підвищеним температурним режимом повітря.

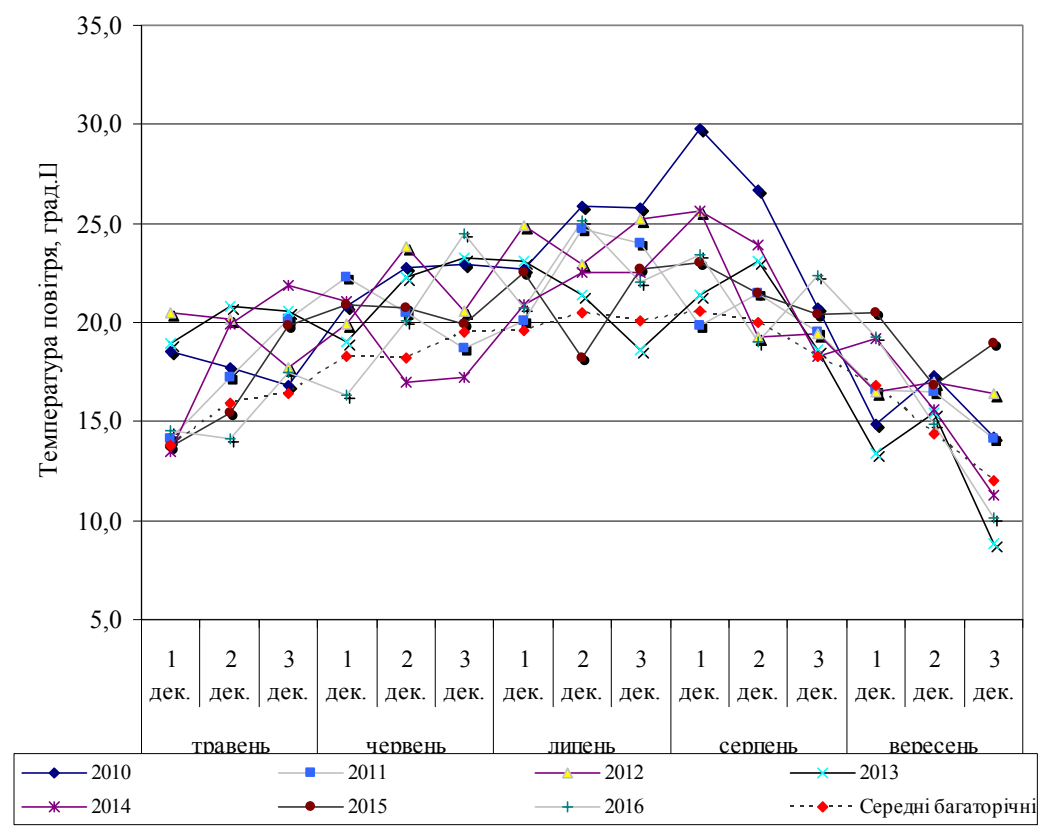

Рис. 1. Погодні умови (середня температура повітря) під час вететації рослин проса прутоподібного, 2010-2016 pp.

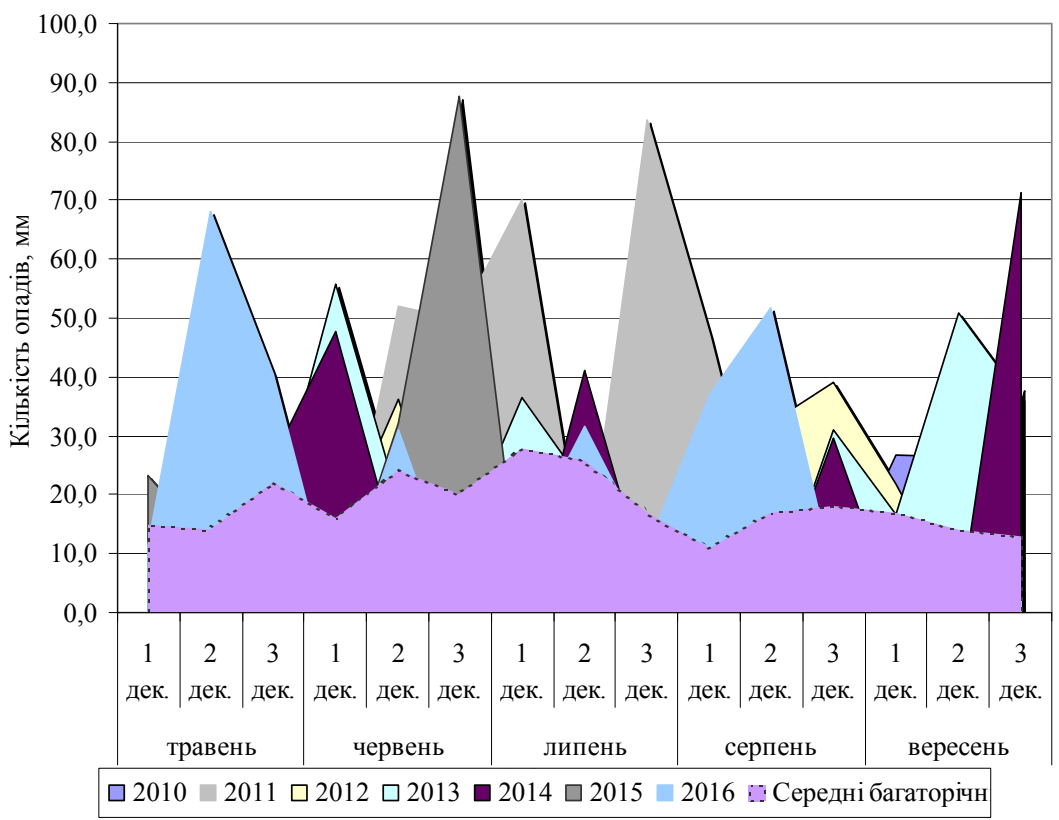

Рис. 2. Погодні умови (сума опадів) під час вететації рослин проса прутоподібного, 2010-2016 рр. 


\section{СІЛЬСЬКЕ ГОСПОДАРСТВО. РОСЛИННИЦТВО}

Сума опадів по рокам дослідження за веснянолітню вегетацію рослин розподілялася нерівномірно: для 2012 року змінювалась у межах - від 2,6 до 32,3 мм, за середнього значення 18,1 мм, у 2013 році - від 0,3 до 55,8 мм (середнє 20,9 мм), у 2014 році - від 0,7 до 77,8 мм (середнє 22,4 мм), у 2015 році - від 0,8 до 87,7 мм (середнє 19,5 мм), у 2016 році - від 2,3 до 68,2 мм (середнє 25,2 мм). Це свідчить про надмірне зволоження у 2013, 2014, 2015 роках та наявність менш зволожених умов вегетації у 2012 році.

Протягом вегетаційного періоду рослин проса прутоподібного відмічено значні відхилення погодних умов у площину збільшення показників середньодобової температури повітря та опадів практично в усі роки - тренд температур (СТ), опадів (КО) та гідротермічного коефіцієнта (ГТК) у весняно-літній період значно відрізнявся від середньобагаторічних даних. Це мало суттєвий вплив на формування елементів продуктивності - кількісних показників рослин. При цьому визначено, що кількість стебел (КС) у рослин проса прутоподібного протягом років дослідження варіювала у межах від 213,5 до 395,4 шт./м.П., висота рослин (ВР) мала тенденцію до збільшення - від 141,5 до 192,4 см.

Проведення кореляційно-регресійного аналізу дало змогу встановити зв'язки між умовами вегетаційного періоду та кількісними показниками рослин проса прутоподібного (табл. 1).

За 2013 та 2016 роки встановлена певна закономірність: густота стеблостою (кількість стебел) має обернений сильний зв'язок із середньодобовою температурою повітря за вегетаційний період (відповідно за роками: r -0,72 i -0,79), середній - із кількістю опадів (відповідно: $r$ 0,34 i 0,39 ) та ГТК (r 0,41 i 0,38). Висота рослин мала обернений зв'язок із температурою (відповідно за роками: $\mathrm{r}-0,36 \mathrm{i}-0,31)$, сумою опадів ( $\mathrm{r} 0,37 \mathrm{i}$ 0,35) та ГТК (r 0,37 i 0,41) за період вегетації культури.

В умовах 2014 і 2015 рp. спостерігалась інша залежність: густота стеблостою обумовлювалася як температурним фактором (відповідно за роками: $\mathrm{r}$-0,69 і -0,71), так і кількістю опадів за вегетацію рослин (г 0,66 і 0,70), в меншій мірі показником ГТК (r 0,57 і 0,61). На висоту рослин суттєвий вплив мала кількість опадів (відповідно за роками: r 0,81 i 0,70), в меншій мірі - сума температур (r 0,37 i 0,35) та ГТК (r -0,31 i -0,32).

\section{1. Кореляційний зв'язок міэ погодними умовами вететаційного періоду та елементами продуктивності (кількість стебел, висота рослин) проса прутоподібного, 2013-2016 рр.}

\begin{tabular}{|c|c|c|c|c|c|c|}
\hline \multirow{2}{*}{ Показники } & \multicolumn{2}{|c|}{2013 рік } & \multirow{2}{*}{$\begin{array}{c}\text { Кореляційний } \\
\text { зв'язок }\end{array}$} & \multicolumn{2}{|c|}{2014 рік } & \multirow{2}{*}{$\begin{array}{c}\text { Кореляційний } \\
\text { зв'язок }\end{array}$} \\
\hline & $\mathrm{KC}$ & $\mathrm{BP}$ & & $\mathrm{KC}$ & $\mathrm{BP}$ & \\
\hline $\mathrm{CT}$ & $-0,72$ & $-0,36$ & сильний/середній & $-0,69$ & $-0,31$ & середній/середній \\
\hline $\mathrm{CO}$ & 0,34 & 0,37 & середній/середній & 0,66 & 0,81 & сильний/сильний \\
\hline ГТК & 0,41 & 0,37 & середній/середній & 0,44 & 0,57 & середній/середній \\
\hline Показники & \multicolumn{2}{|c|}{2015 рік } & - & \multicolumn{2}{|c|}{2016 рік } & - \\
\hline $\mathrm{CT}$ & $-0,71$ & $-0,32$ & сильний/середній & $-0,79$ & $-0,31$ & сильний/середній \\
\hline $\mathrm{CO}$ & 0,75 & 0,70 & сильний/сильний & 0,39 & 0,35 & середній/середній \\
\hline ГТК & 0,61 & 0,50 & середній/середній & 0,38 & 0,41 & середній/середній \\
\hline
\end{tabular}

Примітка: зв'язок суттєвий на 5 \% рівні значущості.

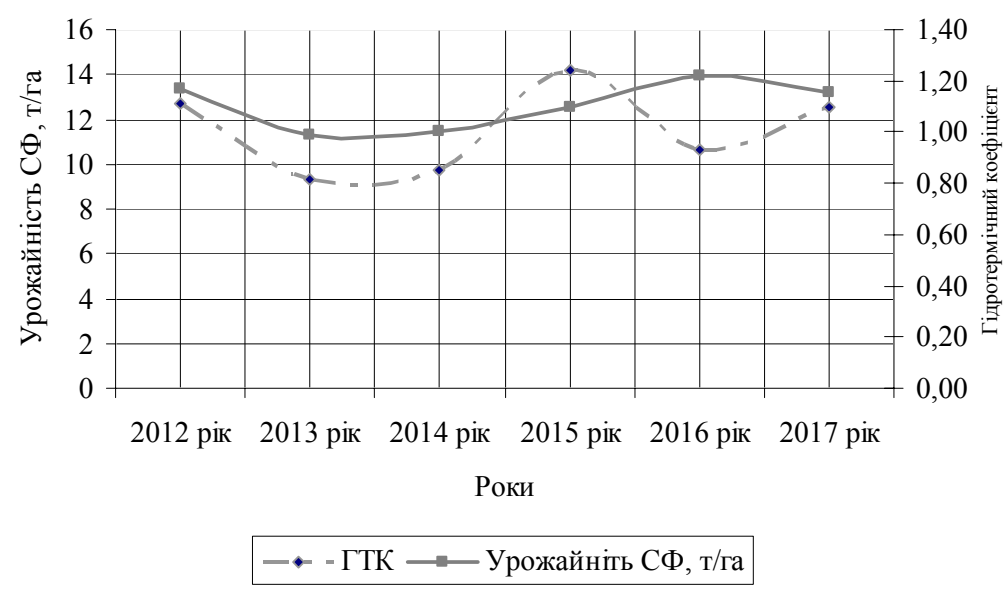

Рис. 2. Урожайність сухої фітомаси (СФ) та гідротермічний коефіцієнт (ГТК) вегетаційного періоду проса прутоподібного, 2013-2017 рр. 
СІЛЬСЬКЕ ГОСПОДАРСТВО. РОСЛИННИЦТВО

2. Кореляційний зв'язок між погодними умовами вететаційного періоду та урожсайністю сухої фітомаси проса прутоподібного, 2013-2016 рр.

\begin{tabular}{|l|c|c|c|c|c|}
\hline \multirow{2}{*}{\multicolumn{1}{|c|}{ Показники }} & \multicolumn{5}{|c|}{ Вегетаційний рік } \\
\cline { 2 - 6 } & 2013 рік & 2014 рік & 2015 рік & 2016 рік & 2017 рік \\
\hline $\begin{array}{l}\text { Середньодобова } \\
\text { температура повітря, }{ }^{\circ} \mathrm{C}\end{array}$ & $-0,70$ & $-0,72$ & $-0,81$ & $-0,77$ & $-0,69$ \\
\hline Сума опадів, мм & 0,04 & 0,02 & 0,03 & 0,02 & 0,05 \\
\hline Гідротермічний коефіцієнт & 0,31 & 0,34 & 0,64 & 0,61 & 0,37 \\
\hline
\end{tabular}

Примітка: * - зв'язки суттєві на 5 \% рівні значущості.

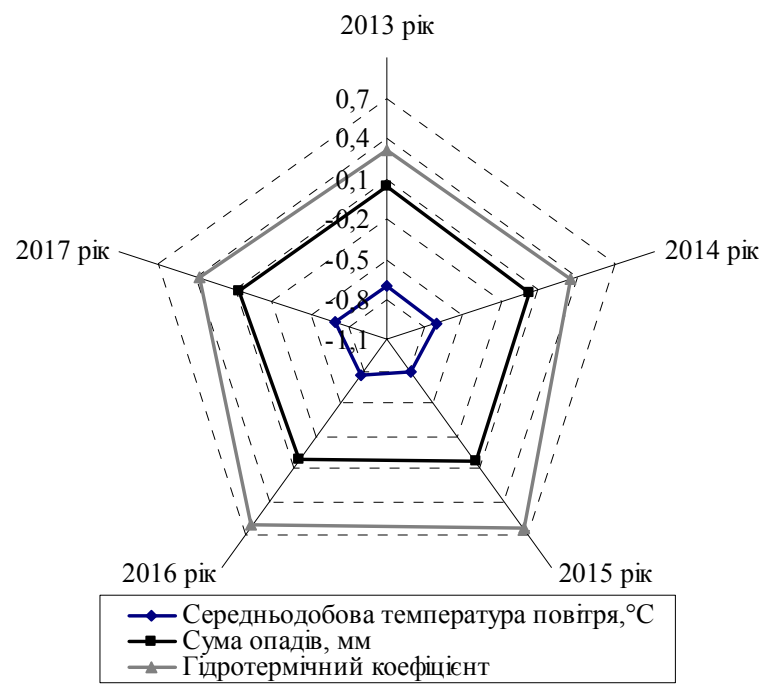

Рис. 3. Кореляційна плеяда залежності урожайності сухої фітомаси проса прутоподібного від погодних умов вететації, 2013-2017 pp.

Примітка: * - зв'язки суттєві на 5 \% рівні значущості.

Гідротермічний коефіціснт, поряд 3 контрастними умовами вирощування, мав посередній вплив на динаміку урожайності сухої фітомаси проса прутоподібного в розрізі років дослідження (рис. 3).

За кореляційною залежністю встановлено, що збільшення урожайності сухої фітомаси проса прутоподібного в більшій мірі визначається кількістю стебел на одиницю площі - коефіцієнт кореляції сильний (r 0,78), ніж висотою рослин коефіцієнт кореляції середній (r 0,39).

Урожайність сухої фітомаси проса прутоподібного мала середній зв'язок із ГТК і змінювалася у межах від 11,3 до 13,9 т/га (за НIP 05 2,23 т/га). Найбільша урожайність культури зафіксована у 2015 і 2016 роках, найменша - у 2013 і 2014 роках.

За проведення кореляційно-регресійного аналізу було встановлено зв'язки між погодними умовами вегетаційного періоду та урожайністю сухої фітомаси проса прутоподібного (табл. 2, рис. 3).

Урожайність фітомаси проса прутоподібного обумовлюється середньодобовою температурою повітря та ГТК за вегетаційний період - на другий та п'ятий-шостий рік життя культури між цими показниками встановлений сильний та середній кореляційний зв'язок. Слабку кореляцію між кількістю опадів за вегетацію і урожайністю проса прутоподібного відмічено в усі роки вегетації культури. Це свідчить про те, що врожайність сухої фітомаси проса прутоподібного в більшій мірі обумовлюється середньодобовою температурою повітря та ГТК, ніж сумою опадів за вегетаційний період.

\section{Висновки:}

1. Кількість стебел у проса прутоподібного протягом років дослідження варіювала у межах від 213,5 до 395,4 шт./м.п. і обумовлювалася середньодобовою температурою повітря, в меншій мірі - кількістю опадів та показником гідротермічного коефіцієнта за вегетаційний період.

2. Висота рослин змінювалася від 141,5 до 192,4 см., суттєвий вплив на цей показник мала кількість опадів (особливо у 2014 і 2015 роках), середній вплив мала сума температур та гідротермічний коефіцієнт.

3. Урожайність фітомаси проса прутоподібного обумовлюється густотою стеблостою і в значній мірі залежить від середньодобової температури повітря та гідротермічного коефіцієнта, менш суттєвий вплив має кількість опадів за вегетаційний період. 


\section{БІБЛІОГРАФІЯ}

1. Боровиков В. П. Statistica. Искусство анализа данных на компьютере: для профессионалов / В. П. Боровиков. - СПб. : Питер, 2003. -688 с.

2. Доспехов Б. А. Методика полевого опыта / Борис Алексеевич Доспехов. - М. : Колос, 1985. $-336 \mathrm{c}$.

3. Кудря С. О. Стан та перспективи розвитку відновлюваної енергетики в Україні / С. О. Кудря // Вісник НАН України, 2015. - Вип. №12. C. 25 .

4. Кулик M. I. Урожайність фітомаси енергетичних культур залежно від умов вирощування та біометричних показників рослин / М. І. Кулик, О. О. Горб, М. А. Галицька // Матеріали Міжнародної науково-практичної конференції «Наукові засади підвищення ефективності сільськогосподарського виробництва», 23-24 жовтня 2017 p. - X. : ХНАУ, 2017. - C. 206-209.

5. Кулик М. И. Трансформация малопродуктивных почв в сельхозугодия с помощью многолетних культур / М. И. Кулик // Материалы Международной научно-практической конференции «Продовольственная безопасность, импортозамещение и социально-экономические проблемы развития АПК» Сибирский НИИ экономики сельского хозяйства Центра агробиотехнологий, 9-10 июня 2016 г. - С. 530-533.

6. Кулик М. I. Формування продуктивності інтродукованого в центральній частині України Panicum virgatum L. (Проса лозоподібного) / М. I. Кулик, С. О. Юрченко // Зб. наук. праць «Фактори експериментальної еволюції організмів». - К. : Укр. т-во генетиків і селекціонерів ім. М. І. Вавилова, 2014. - Т.14. - С. 160-164.

7. Курило В. Л. Біоенергетика в Україні: стан та перспективи розвитку / В. Л. Курило, М. В. Роїк, О. М. Ганженко // Біоенергетика. - 2013. - Вип. №1. - C. 5-10.

8. Методичні рекомендації з проведення основного та передпосівного обробітку грунту і сівби проса лозовидного / [Курило В. Л., Гументик М. Я., Гончарук Г. С. та ін.]. - К. : Інститут біоенергетичних культур і цукрових буряків НААН, 2012. $-26 \mathrm{c}$.

9. Рахметов Д. Б. Panicum virgatum L. - перспективний інтродуцент у Національному ботанічному саду ім. М. М. Гришка НААН України / Д. Б. Рахметов, О. М. Вергун, С. О. Рахметова // Інтродукція рослин. - Вип. 3 (63), 2014. - С. 4-12.
10. Роїк М. В. Методика проведення експертизи сортів проса прутоподібного (Panicum virgatum L.) на відмінність, однорідність і стабільність: Код UPOV: PANIC_VIR / [M. В. Роїк, Д. Б. Рахметов, С. М. Гонтаренко та ін.]. - К., 2012. - УIECP. - $15 \mathrm{c}$.

11. Balasko J. A., Smith D. Influence of Temperature and Nitrogen Fertilization on the Growth and Composition of Switchgrass (Panicum virgatum L.) and Timothy (Phleum pratense L.) at Anthesis (1971) / J. A. Balasko, D. Smith // Agronomy Journal. - Vol. 63, №6. - P. 853-857.

12. Bardgett R. D., Wardle D. A. (2010) Aboveground-Belowground Linkages: Biotic Interactions, Ecosystem Processes and Global Change / R. D. Bardgett, D. A. Wardle // Oxford University Press (Series in Ecology and Evolution). - U.K. : Oxford. -302 p.

13. Kakani V. G., Surabhi G. K., Reddy K. R. Photosynthesis and Fluorescence Responses of $\mathrm{C} 4$ Plant Andropogon gerardii Acclimated to Temperature and Carbon Dioxide (2008) / V. G. Kakani, G. K. Surabhi， K. R. Reddy // Photosynthetica. - Vol. 46, №3. - P. 420-430.

14. Kandel T. P. Response to temperature of upland and lowland cultivars of switchgrass (2005) / T. P. Kandel // Tribhuvan University Nepal. P. 35-41.

15. Kulyk M. Methods of calculation productivity phytomass for switchgrass in Ukraine / M. Kulyk, W. Elbersen. - Poltava, 2012. - 10 p.

16. Modeling the impacts of temperature and precipitation changes on soil $\mathrm{CO}_{2}$ fluxes from a Switchgrass stand recently converted from cropland (2016) / [Lai L., Kumar S., Chintala R., Owens V. N., Clay D., Schumacher J., Nizami A. S., Lee S. S., Rafique R.] // J Environ Sci (China). - May. №43. - P. 15-25.

17. Madakadze I. C. Base temperature for seedling growth and their correlation with chilling sensitivity for warm-season grasses (2003) / I. C. Madakadze, K. A. Stewart, R .M. Madakadze, D. L. Smith // Crop Sci. - №43. - P. 874-878.

18. Sanderson M. A., Wolf D. D. Morphological Development of Switchgrass in Diverse Environments (1995) / M. A. Sanderson, D. D. Wolf // Agronomy Journal. - Vol. 87. - №5. - P. 908915. 